www.nature.com/ejhg

\title{
Psychological consequences of predictive genetic testing: a systematic review
}

\author{
Marita Broadstock ${ }^{1,3}$, Susan Michie ${ }^{2}$ and Theresa Marteau ${ }^{2}$ \\ ${ }^{1}$ Cancer Research Campaign, Department of Oncology, Addenbrooke's Hospital, University of Cambridge; \\ ${ }^{2}$ Psychology and Genetics Research Group, Guy's, King's and St Thomas' Medical and Dental Schools, London, UK
}

The aim of this systematic literature review is to describe the psychological consequences of predictive genetic testing. Five databases were searched for studies using standardised outcome measures and statistical comparison of groups. Studies were selected and coded by two independent researchers. From 899 abstracts, 15 papers, describing 11 data sets, met the selection criteria for the review. The studies were of predictive genetic testing for Huntington's disease, hereditary breast and ovarian cancer, familial adenomatous polyposis and spinocerebellar ataxia. One involved children; the rest were of adults. None of the 15 papers reported increased distress (general and situational distress, anxiety and depression) in carriers or non-carriers at any point during the $\mathbf{1 2}$ months after testing. Both carriers and non-carriers showed decreased distress after testing; this was greater and more rapid amongst non-carriers. Test result (ie being a carrier or non-carrier) was rarely predictive of distress more than one month after testing (predictive in two of 14 analyses). Pre-test emotional state was predictive of subsequent distress in 14 of 27 analyses. There is a lack of informative studies in this field. The studies reviewed suggest that those undergoing predictive genetic testing do not experience adverse psychological consequences. However, the studies are of self-selected populations who have agreed to participate in psychological studies and have been followed up for no more than three years. Most research has been of testing for Huntington's Disease and included follow-up of no more than one year. The results suggest that testing protocols should include a pre-test assessment of emotional state so that post-test counselling can be targeted at those more distressed before testing. None of the studies experimentally manipulated the amount or type of counselling provided. The relationship between counselling and emotional outcome is therefore unclear and awaits empirical study. European Journal of Human Genetics (2000) 8, 731-738.

Keywords: genetic testing; predictive testing; psychological consequences; systematic review; Huntington's disease; breast cancer; ovarian cancer; familial adenomatous polyposis; spinocerebellar ataxia

\section{Introduction}

Predictive genetic tests are being offered for an increasing number of conditions, including single gene conditions, such as Huntington's disease (HD), and multifactorial conditions such as hereditary cancers and familial hypercholes-

Correspondence: Dr S Michie, DPhil, Psychology and Genetics Research Group, Guy's, King's and St Thomas' Medical and Dental Schools, 5th Floor, Thomas Guy House, Guy's Campus, London SE1 9TR, UK. Tel: 0044 (0)20 7955 4955; Fax: 0044 (0)20 7955 2654; E-mail:

susan.michie@kcl.ac.uk

${ }^{3}$ Current address: Dept of Public Health and General Practice, Christchurch School of Medicine, University of Otago, Christchurch, New Zealand

Received 7 March 2000; revised 29 May 2000; accepted 7 June 2000 terlaemia. These tests are offered within a counselling protocol, but there are few data to inform how this should best be done. An important element in informing clinical practice is to understand the impact of undergoing predictive genetic tests upon emotional state, the way people think about themselves and upon behaviours that may help or hinder their health.

The aim of this systematic review is to summarise published, empirical data describing the emotional, cognitive and behavioural consequences of undergoing predictive genetic testing. This will provide a more precise estimate of these consequences than is possible from current reviews. This can form the basis of evaluating current practice as well 
as highlighting gaps and uncertainties in our knowledge, and hence the research questions that need to be addressed in subsequent research.

The review was of studies using standardised outcome measures. For this reason, qualitative studies were not included.

\section{Method}

\section{Search strategy}

Five databases were searched to identify articles (not dissertations or book chapters) which were published in the English language:

(a) Embase (Excerpta Medica, since 1990) search terms: 'genetic screening or genetic disorders or genetic risk or Huntington chorea (congenital, diagnosis, epidemiology)' and 'psychology or psychological aspect or emotional stress or medical psychology or depression or anxiety';

(b) Medline (Index Medicus, since 1990) search terms: 'genetic screening and psychology' or 'Huntington's disease and psychology' or 'hereditary diseases and psychology';

(c) Psychinfo (since 1984) search terms: 'genetics or genetic disorders or congenital disorders or Huntington's chorea' and 'screening or screening tests or medical diagnosis or psychodiagnosis';

(d) Social Sciences Citation Index (since 1990) using the words 'Genetic test*' (ie any word ending) in the title, keyword or abstract;

(e) Science Citation Index: citations of authors of two research groups producing early relevant papers (Tibben and colleagues in The Netherlands, and Wiggins and colleagues in Canada).

To validate results of this search strategy, we investigated whether six relevant references selected from a previous systematic review of risk assessment ${ }^{1}$ were identified in the first three database searches. Medline identified all six, Embase found four of a possible four, and PsychInfo found two of a possible two (somejournals were not included in the databases). There were two additional sources of papers: references cited in identified papers and seven key experts in the field.

\section{Selection of eligible papers}

Abstracts identified from the search strategies were judged for inclusion by MB and SM independently and discrepancies resolved through discussion. Full articles for included abstracts were independently coded for eligibility by the two raters using criteria specified below. There was discordance on two articles which were initially included but then excluded after discussion, giving $96 \%$ concordance.
Papers were excluded if they were:

(1) qualitative (case studies, no standardised outcome measures, and no statistical comparison of groups);

(2) studies of mediators of the outcomes of interest, such as information recall, knowledge or attitudes;

(3) studies of prenatal testing.

\section{Information extraction}

Information extraction sheets were piloted and used by MB and SM to code all articles independently. Any discrepancies were clarified through discussion.

\section{Eligible papers}

We identified 899 abstracts from five databases: 139 from Embase; 344 from Medline, 212 from Psychinfo, and 190 from Social Sciences Index. From these, the following eligible abstracts were identified: 24 from Embase, 26 from M edline, 3 from Psychinfo, 12 from Social Sciences Index, and 14 from Science Citation Index. Given overlap between databases, this produced a total of 43 papers. From the references of these papers, we identified a further seven abstracts all of which were ineligible. Finally, two 'in press' articles (since published) and one 'overlooked article' were obtained after consultation with experts. This gave a total of 46 potentially eligible papers.

\section{Papers selected for review}

On the basis of selection criteria described above, 15 of the 46 articles identified were included in the review (Table1). ${ }^{2-16}$ Reasons for excluding the remaining papers were as follows: 10 were reviews, ${ }^{17-26} 10$ were qualitative, ${ }^{27-36}$ seven reported only pre-test measures, ${ }^{37-43}$ two were of respective attitudes towards testing or used unstandardised measures, ${ }^{44,45}$ and one did not report outcomes for unaffected participants separately from those affected. ${ }^{46}$ One small sample, crosssectional study ${ }^{47}$ was also excluded as it was preliminary to larger, prospective studies conducted by the same group.

\section{Results \\ Description of studies}

Study context Papers concerning the same cohort are considered as single studies, giving 11 data sets reported in 15 papers, all published since 1992 (Table1). Five studies (eight papers) related to Huntington's disease, three studies related to hereditary breast and ovarian cancer (HBOC), one concerned the impact of spinocerebellar ataxia (SCA), and one familial adenomatous polyposis (FAP). Finally, one study (two papers) compared samples offered predictive genetic testing for three adult onset diseases: HD, HBOC and FAP. 54 studies were from the US, two from The Netherlands, and one each from Canada, Belgium and Japan. 
Table 1 Studies assessing psychological consequences of predictive genetic testing

\begin{tabular}{|c|c|c|c|c|}
\hline Authors & Condition & Country of study & Assessment timepoints & Emotional outcomes $^{a}$ \\
\hline Codori et $\mathrm{al}^{2}$ & HD & United States & base, $3 m, 6 m, 9 m, 12 m$ & Depr: BDI, BHS \\
\hline Decruyenaere et $\mathrm{al}^{3}$ & HD & Belgium & base, $1 \mathrm{~m}, 12 \mathrm{~m}$ & Depr: BDI; Anx: STAl \\
\hline $\begin{array}{l}\text { Wiggins et al } \\
\text { Lawson } 5\end{array}$ & HD & Canada & base, $7-10 \mathrm{~d}, 6 \mathrm{~m}, 12 \mathrm{~m}$ & Depr: BDI; Gen Distr: GSI \\
\hline Quaid, Wesson ${ }^{6}$ & $H D$ & United States & base, $3 m, 6 m, 9 m, 12 m$ & Depr: BDI, BHS; Gen Distr: SCL9OR, MSI \\
\hline $\begin{array}{l}\text { Tibben et } \mathrm{al}^{7} \\
\text { Tibben et } \mathrm{al}^{8} \\
\text { Tibben et } \mathrm{al}^{9}\end{array}$ & HD & Netherlands & base, $1 w, 6 m, 3 y$ & Depr: BHS; Gen Distr: GHQ60; Sit Dist: IES \\
\hline $\begin{array}{l}\text { Dudok de Wit et al } \\
\text { Dudok de Wit et al } \\
\text { Di1 }\end{array}$ & $\begin{array}{l}\mathrm{HD}, \mathrm{HBOC} \\
\text { FAP }\end{array}$ & Netherlands & base, $1 w, 6 m$ & Sit Dist: IES \\
\hline Croyle et al ${ }^{12}$ & $\mathrm{HBOC}$ & United States & base, $1-2 w$ & Anx: STAl; Sit Dist: IES \\
\hline Lerman et al ${ }^{13}$ & $\mathrm{HBOC}$ & United States & base, 1 & Depr: CES-D; Gen Distr: MOS \\
\hline Lerman et al ${ }^{14}$ & $\mathrm{HBOC}$ & United States & base, $1 \mathrm{~m}, 6 \mathrm{~m}$ & Depr: CES-D \\
\hline Codori et $\mathrm{al}^{15}$ & FAP & United States & base, $3 \mathrm{~m}$ & Depr: CDI, RADS; Anx: RCMAS \\
\hline Abe, Itoyama ${ }^{16}$ & SCA & Japan & base, $1 w, 6 m, 12 m$ & Depr: SDS; Anx: STAI \\
\hline
\end{tabular}

d: days; w: weeks; m: months; y: years; Depr: depression; Anx: anxiety; Gen Distr: general distress; Sit Dist: situational distress; Well-B: well-being. afor detail of measures, see Method.

Design All studies employed prospective designs with a predisclosure baseline assessment and between one and four assessments post disclosure (Table 1 ).

Response and retention rates Response rates to studies ranged from 66 to $99 \%$ at baselinefor the six studies in which they were reported (Table2). Final retention rates ranged from $42 \%$ to $85 \%$ in the five studies reporting this information.

Participants Whilst all studies compared mutation carriers with non-carriers, three also assessed psychological consequences for decliners, and one study included those for whom no definitive test result was available (Table2). All papers concerned adults over 18years (mean ages ranged from 32 to 43) with the exception of one which investigated genetic testing in children aged six to 16 years. ${ }^{15}$ The proportion of women in the studies ranged from $44 \%$ to $80 \%$, with one comprising women only. ${ }^{12}$ Only five studies gave details of ethnicity of participants; four reported overwhelmingly white samples and one was of Japanese participants. ${ }^{16}$ The number of families represented by partici- pants ranged from one to 33 in the five studies that reported this.

Outcome measures All the consequences assessed in the review studies were of, or related to, emotion. These were depression (nine studies), state anxiety (four studies), general distress (four studies) and situational distress exhibited by intrusive thoughts and attempts to avoid these thoughts (three studies). Depression was measured by the Beck Depression Inventory (BDI), ${ }^{48}$ the Beck Hopelessness Scale (BHS), ${ }^{49}$ the Center for Epidemiological Studies Depression Scale (CESD-S), ${ }^{50}$ the Social Desirability Scale (SDS), ${ }^{51}$ subscale of the Minnesota Multiphasic Personality Inventory (MMPI), ${ }^{52}$ for children, the Children's Depression Inventory (CDI), ${ }^{53}$ and for adolescents, the Reynold's Adolescent Depression Scale (RADS). ${ }^{54}$ Anxiety was measured by the state subscale of the State Trait Anxiety Inventory (STAI), ${ }^{55}$ and for children, the Revised Children's Manifest Anxiety Scale (RCMAS). ${ }^{56}$ General distress was measured by subscales of the revised Symptom Check List 90-R (SCL-90-R) ${ }^{57}$ including the General Severity Index (GSI), the General Health Questionnaire

Table 2 Response and retention rates, and sample breakdown by carrier status, age and gender

\begin{tabular}{|c|c|c|c|c|c|c|c|c|c|c|}
\hline Ref. & $\begin{array}{l}\text { Number } \\
\text { approached }\end{array}$ & $\begin{array}{l}\text { Baseline } \\
\text { response }\end{array}$ & $\begin{array}{l}\text { Retention } \\
\text { at follow up }\end{array}$ & $\begin{array}{l}\text { Retention } \\
\text { overall }\end{array}$ & $\mathrm{C}$ & $\mathrm{NC}$ & $\mathrm{D}$ & NRA & $\begin{array}{l}\text { Participant } \\
\text { age (mean) }\end{array}$ & $\begin{array}{l}\text { Participant } \\
\text { gender ( } \% \text { female) }\end{array}$ \\
\hline 2 & NR & NR & $69 \%$ & NR & 52 & 107 & 0 & 0 & 34.4 & $57 \%$ \\
\hline 3 & 50 & $92 \%$ & $91 \%$ & $84 \%$ & 22 & 24 & 0 & 0 & 34.1 & $58 \%$ \\
\hline $4 / 5$ & 190 & $71 \%$ & $82 \%$ & $58 \%$ & 37 & 58 & 23 & 17 & 37.5 & $67 \%$ \\
\hline 6 & 32 & $78 \%$ & $76 \%$ & $59 \%$ & 5 & 14 & 0 & 0 & 36.9 & $44 \%$ \\
\hline $7 / 8 / 9$ & 74 & $99 \%$ & $67 \%$ & $66 \%$ & 29 & 44 & 0 & 0 & 32.2 & $69 \%$ \\
\hline $10 / 11$ & 137 & $66 \%$ & $64 \%$ & $42 \%$ & 20 & 38 & 0 & 0 & $39.5,42.6,28.6^{a}$ & $56 \%, 61 \%, 80 \%^{a}$ \\
\hline 13 & 279 & NR & NR & NR & NR & NR & 67 & 0 & NR & NR \\
\hline 14 & NR & NR & $82 \%$ & NR & 97 & 109 & 121 & 0 & 45 & $68 \%$ \\
\hline 15 & NR & NR & NR & NR & 19 & 22 & 0 & 0 & 11.2 & $58 \%$ \\
\hline 16 & 34 & $74 \%$ & NR & NR & 6 & 19 & 0 & 0 & 32.3 & $64 \%$ \\
\hline
\end{tabular}

C: Carriers; NC: Non carriers; D: Decliners; NRA: no clear test result available; NR: not reported. ${ }^{2}$ Data for HD, HBOC, FAP, respectively. 
(GHQ60), ${ }^{58}$ the Medical Outcomes Study (MOS) subscales of role functioning ${ }^{59}$ and sexual functioning, ${ }^{60}$ the General Well-Being Scale (GWBS), ${ }^{61}$ and the sexual dissatisfaction scal e of the Marital Satisfaction Inventory (MSI). ${ }^{62}$ Situational distress was measured by the Impact of Events subscales: Intrusion and Avoidance (IES). ${ }^{63}$

In addition, measures for predictor variables included personality (subscales of the MMPI), coping (Utrechtse Coping List), ${ }^{64}$ number of, and satisfaction with, supportive persons (subscales of the Social Support Questionnaire), ${ }^{65}$ family functioning (Family Adaptability and Cohesion Evaluation Scales), ${ }^{66}$ and Ioneliness (Loneliness Scale). ${ }^{67}$

\section{Results of studies}

Within group changes in emotion Five of the 11 studies investigated emotional change over time amongst carriers and non-carriers. In none of the 18 analyses did carriers show any change over the first six months following disclosure (Table3). At 12 months, two out of seven analyses revealed changes, with both showing a decrease in depression and general distress. Non-carriers, at all follow-up time points, showed either no change (12 analyses) or decreased depression, anxiety or distress (12 analyses) (Table4). In the one study of those who declined testing or for whom no test results were available, there was no change in depression or distress but a decrease in well-being after six and 12 months. ${ }^{4}$ In all studies, emotional states remained within the normal ranges.

Between group changes in emotion Several studies investigated differences between carriers and non-carriers in the magnitude of emotional change following receipt of test results (Table5). Within the first month, five out of nine analyses showed a greater decrease in depression and general distress for non-carriers than for carriers. By six months, this was found in only one out of six analyses. No differences were found at 12 months (three analyses) or at three years (three analyses) in any emotional outcome measured.

Predictors of emotional consequences There were insufficient data to draw any general conclusions about consequences within a month of testing. Variables predicting consequences more than one month after testing were investigated using multiple regressions, ${ }^{3,7,10,11}$ logistic regressions, ${ }^{10}$ random effects modelling, ${ }^{2}$ non-parametric tests, ${ }^{6}$ and parametric analyses of variance. ${ }^{15}$ The two variables most often used to predict emotional consequences were test result and pre-test emotional state.

Table 3 Number of study analyses reporting no change, decrease, or increase in distress amongst carriers across first year follow up

\begin{tabular}{|c|c|c|c|c|c|c|c|c|c|}
\hline \multirow[b]{2}{*}{ Outcome } & \multicolumn{3}{|c|}{1 month or less } & \multicolumn{3}{|c|}{$3 / 6$ months } & \multicolumn{3}{|c|}{12 months } \\
\hline & No change & Decrease & Increase & No change & Decrease & Increase & No change & Decrease & Increase \\
\hline Depression & $3^{3,4,16}$ & - & - & $3^{4,15,16}$ & - & - & $2^{3,16}$ & $1^{4}$ & - \\
\hline Anxiety & $2^{3,16}$ & - & - & $2^{15,16}$ & - & - & $2^{3,16}$ & - & - \\
\hline General distress & $2^{4 a, b}$ & - & - & $2^{4 a, b}$ & - & - & $1^{4 b}$ & $1^{4 a}$ & - \\
\hline Situational distress & $2^{11 c, d}$ & - & - & $2^{11 c, d}$ & - & - & - & - & - \\
\hline
\end{tabular}

-no analysis performed; a General Severity Index; ${ }^{b}$ well-being; cavoidance; dintrusion.

Table 4 Number of study analyses reporting no change, decrease, or increase in distress amongst non carriers across first year follow up

\begin{tabular}{|c|c|c|c|c|c|c|c|c|c|}
\hline \multirow[b]{2}{*}{ Outcome } & \multicolumn{3}{|c|}{1 month or less } & \multicolumn{3}{|c|}{$3 / 6$ months } & \multicolumn{3}{|c|}{12 months } \\
\hline & No change & Decrease & Increase & No change & Decrease & Increase & No change & Decrease & Increase \\
\hline Depression & $1^{16}$ & $2^{3,4}$ & - & $3^{4,15,16}$ & - & - & $1^{16}$ & $1^{3}$ & - \\
\hline Anxiety & - & $2^{3,16}$ & - & $1^{15}$ & $1^{16}$ & - & - & $2^{3,16}$ & - \\
\hline General distress & - & $2^{4 a, b}$ & - & $1^{4 b}$ & $1^{4 a}$ & - & $1^{4 b}$ & $1^{4 a}$ & - \\
\hline Situational distress & - & $2^{11 c, d}$ & - & - & $2^{11 c, d}$ & - & - & - & - \\
\hline
\end{tabular}

-no analysis performed; a General Severity Index; ${ }^{b}$ well-being; cavoidance; ${ }^{d}$ intrusion.

Table 5 Proportion of study analyses in which distress decreased between baseline and follow-up for non carriers more than for carriers

\begin{tabular}{llll}
\hline Outcome & 1 month or less & 6 months & 3 years \\
\hline Depression & $3^{4,9,13} / 3$ & $0 / 2^{4,9}$ & $0 / 2^{3,4 g}$ \\
Anxiety & - & - & $0 / 1^{8}$ \\
General distress & $2^{4 a, 13 e / 4^{4 a, b, 13 e, f}}$ & $0 / 2^{4 a, b}$ & - \\
Situation distress & $0 / 2^{9 c, d}$ & $1^{9 c / 2^{9 c, d}}$ & $0 / 2^{4 a, b}$ \\
\hline
\end{tabular}

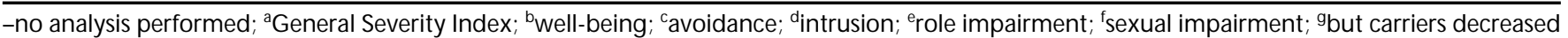
in depression from baseline to 12 month follow-up more than non-carriers. 
Table 6 Proportion of study analyses predicting distress more than one month later

\begin{tabular}{|c|c|c|c|c|c|}
\hline Variables & Baseline predictors & Depression & Anxiety & General distress & Situational distress \\
\hline Test result & Carrier vs non-carrier & $0 / 7^{2,3,6,7,15}$ & $0 / 1^{15}$ & $1^{6} / 2^{6}$ & $1^{7} / 4^{7,10}$ \\
\hline $\begin{array}{l}\text { Pretest } \\
\text { Emotional } \\
\text { State }\end{array}$ & $\begin{array}{l}\text { Depression } \\
\text { Anxiety } \\
\text { General distress } \\
\text { Situational distress }\end{array}$ & $\begin{array}{l}4^{2,3,7} / 4 \\
0 / 1^{7} \\
1^{7} / 2^{7}(-)\end{array}$ & & & $\begin{array}{l}2^{10} / 6^{7,10} \\
1^{10} / 2^{10}(-) \\
0 / 4^{7,10} \\
6^{7,10 /} 8^{7,10}\end{array}$ \\
\hline Other & $\begin{array}{l}\text { Female } \\
\text { Age } \\
\text { Having a partner } \\
\text { Have children } \\
\text { No religious conviction } \\
\text { Have affected mother } \\
\text { Closer to onset (carriers only) } \\
\text { Direct test vs linkage } \\
\text { Perceived higher risk } \\
\text { Risk of HD/FAP vs HBOC } \\
\text { Coping } \\
\text { Personality } \\
\text { Low satisfaction } \\
\text { with social support } \\
\text { Number of supportive persons } \\
\text { Family functioning } \\
\text { Loneliness }\end{array}$ & $\begin{array}{l}0 / 4^{2,3,11} \\
0 / 2^{3,11} \\
0 / 2^{2} \\
0 / 2^{2} \\
0 / 1^{15} \\
1^{2} / 2^{2} \\
1^{2} / 4^{2,3,11} \\
0 / 2^{2} \\
0 / 1^{3} \\
0 / 1^{3} \\
1^{7} / 1 \\
0 / 1^{7}\end{array}$ & $1^{15} / 1$ & & $\begin{array}{l}1^{10} / 2^{10} \\
1^{7} / 4^{7,10} \\
1^{10} / 4^{7,10} \\
0 / 2^{10} \\
0 / 2^{10}\end{array}$ \\
\hline
\end{tabular}

(-) demonstrates a negative relationship between predictor and outcome.

(a) Test result did not predict emotional consequences in 12 out of 14 analyses (Table 6). The two exceptions found that being a carrier predicted distress;

(b) Pre-test emotional state was predictive of subsequent depression and situational distress in 14 out of 27 analyses (Table6).

(c) A variety of other demographic and social variables have been investigated, as listed in Table6, but there were insufficient numbers of analyses to draw any conclusions.

\section{Discussion}

The results of this systematic review found a lack of informative studies in this field. Although there were some studies of emotional outcome, there were none reporting cognitive or behavioural outcomes meeting our review criteria. The studies reviewed found no evidence of abnormally high levels of, nor increases in, emotional distress in mutation carriers or non-carriers at any point during three years after predictive genetic testing. Both carriers and noncarriers showed decreased distress after testing, with this being greater and more rapid amongst non-carriers. Test result (ie being a carrier or non-carrier) was rarely predictive of distress more than one month after testing, in contrast with pre-test emotional state which was a stronger predictor.

These results reflect studies that are of self-selected individuals. Many of the study samples were recruited from families on research registers during the early stages of the test being offered, sometimes following linkage studies requiring longterm commitment and family contact. There is some evidence that those coming forward for testing are more resourceful and emotionally more robust than others. One study found that those undergoing testing for HD had higher ego strength, were more socially extroverted, and had more positive coping strategies than the general population. ${ }^{37}$ This is consistent with a study comparing those undergoing HD testing with untested members of an HD association that found the latter had a more pessimistic outlook on their futures. ${ }^{43}$ It should also be noted that the majority of studies are of HD and there are insufficient studies of other conditions to ascertain the generalisability of these results.

In addition, further response bias is caused by selective drop-out over time. The three year follow-up study reported by Tibben and colleagues ${ }^{9}$ suggested that non-carriers who no longer saw HD as a problem in their lives were more likely to drop out of the study. This would have the effect of masking possible adverse effects.

A further explanation for the lack of adverse psychological outcomes is that protective psychological mechanisms may be at work. Tibben and colleagues ${ }^{9}$ suggest that the responses of carriers who continued in their study reflected denial, relief from uncertainty, or both. In addition, individuals from at risk families may have developed effective coping mechanisms. This is supported by research findings that those at high risk show less extreme emotional responses than the general population undergoing screening. ${ }^{22}$ In reporting the results, overall means have been presented. Although some papers have identified sub-groups of people with high anxiety or depression, the lack of comparison amongst the 
untested population makes the interpretation of these findings problematic.

Whilst this review did not find evidence of increased distress for those tested, recent research has suggested that there may be adverse reactions among those who are found to be carriers for HD. In a survey in 21 countries, Almqvist et $\mathrm{al}^{68}$ collected information about the frequency of catastrophic events (suicide, suicide attempt, or psychiatric hospital isation) occurring after predictive testing for HD. The study found that $2 \%$ of identified carriers and $0.3 \%$ of noncarriers experienced a catastrophic event during follow-up. However, of those experiencing a catastrophic event within a year of testing, the majority were symptomatic for the disease at the time of the event, suggesting that the onset of HD is a contributing factor. Whilst those informed that they were carriers had a higher suicide rate than the general population, it was not higher than those generally symptomatic for HD. ${ }^{69}$ This suggests that presymptomatic testing has not increased distress above levels generally found in those with HD.

To those unfamiliar with this area, it may be surprising that test results rarely predict emotional outcomes. Several factors seem to be influencing emotional consequences of testing: awareness of pre-test risk status, psychological coping mechanisms, sample selection and counselling. This may be because the psychological benefit of relief from uncertainty pertains to both carriers and non-carriers. ${ }^{44}$ The difficulties posed by a change in self identity and relationships with other family members may also occur irrespective of test result. Another explanation for test result not predicting emotional outcome is the coping mechanisms that many individuals use in the face of a threat. One such mechanism is threat minimisation, whereby those facing a threat (eg a positive result) perceive it to be less serious than those not facing the threat. ${ }^{70}$ The pattern of results in several studies are compatible with this type of coping. ${ }^{44}$

This review detected no differences in the pattern of results across the two most commonly studied conditions, HD and $\mathrm{HBOC}$, suggesting that the treatability of the condition is not a key factor in determining emotional responses. We consider the reliability of the findings from the studies of HD to be high, given their replication, sufficient numbers and follow-up. However, it is likely to be lower for HBOC because there were only two data sets and a short follow-up. Finally, the reliability of the findings for FAP and SCA is likely to be low since the first included children and the second was the only study to be carried out in Japan. A limitation of non-HD studies is that some of the samples are small and families tend to be represented by several members, reducing sample heterogeneity. Since the statistical power of some of these studies is low, the lack of differences cannot be considered to be a robust finding. Large international studies using standardised measures are needed to examine differences in psychological consequences of genetic testing across disease domains and testing environments.
Some data identified in the process of this review could not be used since the results were presented for unaffected and affected people together ${ }^{12-14}$ including one ${ }^{46}$ which investigated the moderating effect of siblings' test results. Genetic information has implications for the families of those tested and, although beyond the scope of the review, data have been collected on the impact of testing for HD on untested partners, ${ }^{6,9}$ children undergoing testing for $\mathrm{FAP}^{71}$ and parents of children tested for FAP. ${ }^{15}$

The results of these studies pertain to the first three years after testing. It may be that carriers experience increased distress as they approach the likely onset of their condition. Prospective studies over longer time periods are needed, as are experimental studies manipulating the amount and type of counselling. Noticeably absent from published studies are cognitive or behavioural outcome measures. Given the suggestion that genetic risk information may be associated with a sense of fatalism, ${ }^{72}$ this is an area deserving attention. For multifactorial conditions, this is especially important. It may be that genetic information leads to risks being perceived as unmodifiable and to less adherence to behaviours that would lower health risks.

This review suggests that testing protocols should includea pre-test assessment of emotional state so that post-test counselling can be targeted at those more distressed before testing. This conclusion is consistent with Almqvist et al's $s^{68}$ international survey which indicated that $38.5 \%$ of those experiencing a catastrophic event after predictive testing had a prior psychiatric history. In view of this, it has also been argued that prior to testing, those with depression should be seen by a psychiatrist or a clinical psychologist with a view to treatment for the condition before testing occurs. ${ }^{69}$

Much of predictive genetic testing is currently being offered within research programmes, with protections of ethical review, and protocols for extensive pre- and post-test counselling and follow-up, often staged over months. As genetic testing is diffused from this academic context into routine clinical practice, some of the protective factors associated with the research environment are likely to be reduced. ${ }^{73}$ Higher rates of adverse consequences for those tested may occur. ${ }^{69}$ We do not at present know how much or what type of information and support are required, or when counselling should be provided in relation to decisionmaking, test feedback, and follow-up. None of these studies experimentally manipulated the amount or type of counselling provided, making the relationship between counselling and emotional outcome unclear. There is a pressing need for experimental studies to address this question.

\section{Acknowledgements}

This research was funded as part of an NHS R\&D grant, RCC56266 'The psychological impact of genetic testing for hereditary breast and ovarian cancer: a pilot study'. Susan Michie and Theresa Marteau are funded by The Wellcome Trust. 


\section{References}

1 Shaw C, Abrams K, Marteau TM: Psychological impact of predicting individual's risk of illness: A systematic review. Soc Sci Med 1999; 49: 1571-1598.

2 Codori AM, Slavney PR, Young C, Miglioretti DL, Brandt J: Predictors of psychological adjustment to genetic testing for Huntington's disease. Health Psychol 1997; 16: 36-50.

3 Decruyenaere M, Evers-Kiebooms G, Boogaerts A et al: Prediction of psychological functioning one year after the predictive test for Huntington's disease and impact of the test result on reproductive decision making. J Med Genet 1996; 33: 737-743.

4 Wiggins $S$, Whyte $P$, Huggins $M$ et al: The psychological consequences of predictive testing for Huntington's disease. N ew Engl J Med 1992; 327: 1401-1405.

5 Lawson K, Wiggins S, Green T et al: Adverse psychological events occurring in the first year after predictive testing for Huntington's disease. J Med Genet 1996; 33: 856-862.

6 Quaid KA, Wesson MK: Exploration of the effects of predictive testing for Huntington disease on intimate relationships. Am J Med Genet 1995; 57: 46-51.

7 Tibben A, Duivenvoorden $\mathrm{HJ}$, Vegter-van der Vlis $M$ et al: Presymptomatic DNA testing for Huntington disease: Identifying the need for psychological intervention. Am J Med Genet 1993; 48: 137-144.

8 Tibben A, Duivenvoorden HJ, Niermeijer MF, Vegter-van der Vlis $M$, Roos RAC, Verhage F: Psychological effects of presymptomatic DNA testing for Huntington's disease in the Dutch program. Psychosom Med 1994; 56: 526-532.

9 Tibben A, Timman R, Bannink EC, Duivenvoorden HJ: Three-year follow-up after presymptomatic testing for Huntington's disease in tested individuals and partners. Health Psychol 1997; 16: 20-35.

10 Dudok de Wit AC, Duivenvoorden HJ, Passchier J et al: Course of distress experienced by persons at risk for an autosomal dominant inherited disorder participating in a predictive testing program: An exploratory study. Psychosom Med 1998; 60: 543-549.

11 Dudok de Wit AC, Tibben A, Duivenvoorden $\mathrm{HJ}$ et al: Predicting adaptation to presymptomatic DNA-testing for late onset disorders: who will experience distress? J Med Genet 1998; 35: 745-754.

12 Croyle RT, Smith KR, Botkin JR, Baty B, Nash J: Psychological responses to BRCA1 mutation testing: preliminary findings. Health Psychol 1997; 16: 63-72.

13 Lerman $\mathrm{C}$, Narod S, Schulman $\mathrm{K}$ et al: BRCA1 testing in families with hereditary breast-ovarian cancer: A prospective study of patient decision making and outcomes. JAMA 1996; 275: 1885-1892.

14 Lerman C, Hughes C, Lemon SJ et al: What you don't know can hurt you: Adverse psychologic effects in members of BRCA1linked and BRCA2-linked families who decline genetic testing. J Clin Oncol 1998; 16: 1650-1654.

15 Codori AM, Petersen GM, Boyd PA, Brandt J, Giardiello FM: Genetic testing for cancer in children. Short-term psychological effect. Arch Pediatr Adolesc Med 1996; 150: 1131-1138.

16 Abe K, Itoyama Y: Psychological consequences of genetic testing for spinocerebellar ataxia in the Japanese. Eur J Neurol 1997; 4: 593-600.

17 Biesecker BB: Genetic testing for cancer predisposition. Cancer Nurs 1997; 20: 285-296.

18 Bundey S: Few psychological consequences of presymptomatic testing for Huntington disease. Lancet 1997; 349: 4.

19 Codori A-M: Psychological opportunities and hazards in predictive genetic testing for cancer risk. Gastroenterol Clin N Am 1997; 26(1): 19-39.

20 Fryer A: The genetic testing of children. J Roy Soc Med 1997; 90: 419-421.

21 Kodish E, Wiesner GL, MehIman M, Murray T: Genetic testing for cancer risk: how to reconcile the conflicts. JAMA 1998; 279: 179-181.
22 Marteau TM, Croyle RT: The new genetics: Psychological responses to genetic testing. BMJ 1998; 316: 693-696.

23 Mlynik-Szmid A: Psychological consequences of presymptomatic testing for Huntington's disease. Lancet 1997; 349: 808.

24 Olopade OI: Genetic testing of families with hereditary diseases. JAMA 1996; 276(14): 1138.

25 Tibben A, Vegter-vd Vlis M, Skraastad MI et al: Presymptomatic DNA-testing for Huntington disease in the Netherlands. Birth Defects 1992; 28: 127-131.

26 Zak JP, Zaglul JT, Mueller OT, Diamond T: Presymptomatic testing for Huntington's disease. Emotional aspects. J Fla M ed Assoc 1994; 81: 109-112.

27 Bloch M, Adam S, Wiggins S, Huggins M, Hayden MR: Predictive testing for Huntington disease in Canada: The experience of those receiving an increased risk. Am J Med Genet 1992; 42: 499-507.

28 Brandt J, Quaid KA, Folstein SE: Presymptomatic DNA testing for Huntington's disease. J Neuropsychiatr Clin Neurosci 1989; 1: 195-197.

29 Byrne AP, Bamforth S: Genetic testing and Huntington's disease. Ir J Psychol Med 1994; 11: 103.

30 Grossfeld FJ, Lips C], Ten Kroode HF, Beemer FA, Van Spijker HG, Brouwers-Smalbraak GJ: Psychosocial consequences of DNA analysis for MEN type2. Oncology 1996; 10: 141-6.

31 Hayes CV: Genetic testing for Huntington's disease - A family issue. N Engl J Med 1992; 327: 1449-1451.

32 Holloway S, Mennie M, Crosbie A et al: Predictive testing for Huntington disease: Social characteristics and knowledge of applicants, attitudes to the test procedure and decisions made after testing. Clin Genet 1994; 46: 175-180.

33 Huggins $M$, Bloch $M$, Wiggins $S$ et al: Predictive testing for Huntington disease in Canada: adverse effects and unexpected results in those receiving a decreased risk. Am J Med Genet 1992; 42: $508-515$.

34 Lynch HT, Watson P, Conway TA et al: DNA screening for breast/ ovarian cancer susceptibility based on linked markers. Arch Intern Med 1993; 153: 1979-1987.

35 Taylor CA, Myers RH: Long-term impact of Huntington disease linkage testing. Am J Med Genet 1997; 70: 365-370.

36 Watson M, Lloyd SM, Eeles R et al: Psychosocial impact of testing (by linkage) for the BRCA1 breast cancer gene - An investigation of 2 families in the research setting. Oncology 1996; 5: 233-239.

37 Decruyenaere M, Evers-Kiebooms G, Boogaerts A et al: Predictive testing for Huntington's disease: risk perception, reasons for testing and psychological profile of test applicants. Genet Couns 1995; 6: 1-13.

38 Decruyenaere M, Evers-Kiebooms G, Boogaerts A et al: Nonparticipation in predictive testing for Huntington's disease: individual decision-making, personality and avoidant behaviour in the family. Eur J Hum Genet 1997; 5: 351-363.

39 Dudokde Wit AC, Tibben A, Duivenvoorden HJ et al: Psychological distress in applicants for predictive DNA testing for autosomnal dominant, heritable, late onset disorders. J Med Genet 1997; 34: 382-390.

40 Dudokde Wit AC, Tibben A, Duivenvoorden $\mathrm{HJ}$ et al: Distress in individuals facing predictive DNA testing for autosomnal dominant late-onset disorders: Comparing questionnaire results with in-depth interviews. Am J Med Genet 1998; 75: 62-74.

41 Shiwach RS, Norbury CG: A controlled psychiatric study of individuals at risk for Huntingtons Disease. Br J Psychiatr 1994; 165: 500-505.

42 Tyler A, Morris M, Lazarou L, Meredith L, Myring J, Harper P: Presymptomatic testing for Huntington's disease in Wales 1987-90. Br J Psychiatr 1992; 161: 481-484.

43 Van der Steenstraten IM, Tibben A, Roos RAC, Van de Kamp JJP, Niermeijer MF: Predictive testing for Huntington disease: Nonparticipants compared with participants in the Dutch program. Am J Med Genet 1994; 55: 618-625.

44 Codori A-M, Brandt J: Psychological costs and benefits of predictive testing for Huntington's disease. Am J Med Genet 1994; 54: 174-184. 
45 Tibben A, Frets PG, van de Kamp JJ et al: On attitudes and appreciation 6 months after predictive DNA testing for Huntington disease in the Dutch program. Am J Med Genet 1993; 48: 103-111.

46 Smith KR, West JA, Croyle RT, Botkin JR: Familial context of genetic testing for cancer susceptibility: moderating effect of siblings' test results on psychological distress one to two weeks after BRCA1 mutation testing. Cancer Epidemiol Biomarkers Prev 1999; 8: 385-392.

47 Tibben A, Vegter-van der Vlis M, Skraastad MI et al: DNA-testing for Huntington's disease in The Netherlands: a retrospective study on psychosocial effects. Am J Med Genet 1992; 44: 94-99.

48 Beck AT, Ward $\mathrm{CH}$, Mendelson M, Mock J, Erbaugh J: An inventory for measuring depression. Arch Gen Psychiatr 1961; 4: 561-571.

49 Beck AT, Weissman A, Lester D, Trexler L: The measurement of pessimism: The Hopelessness Scale. J Consult Clin Psychol 1974; 42: 861-865.

50 Radloff LS: The CES-D Scale: A self-report depression scale for research in the general population. Appl Psychol Meas 1977; 1: 385-401.

51 Crowne DP: A new scale of social desirability independent of psychopathology. J Cons Psych 1960; 24: 349-354.

52 Graham JR: The M MPI. A Practical Guide. Oxford University Press: New York, 1987.

53 Kovacs M: Children's Depression Inventory. Multi-Health Systems Inc: New York, 1992.

54 Reynolds WM: Reynold's Adolescent Depression Scale. Psychosocial Assessment Resources: Odessa (FI), 1986.

55 Spielberger CD, Gorsuch RL, Lushene RE: STAI Manual. Consulting Psychologist Press: Palo Alto (CA), 1970, pp 23-49.

56 Reynolds CR, Richmond BO: Revised Children's Manifest Anxiety Scale. Western Psychological Services: Los Angeles, 1985.

57 Derogatis LR: SCL-90-R: Manual-II. Clinical Psychometric Research: Towson (MD), 1983.

58 Goldberg DP: The Detection of Psychiatric IIIness by Questionnaire. Oxford University Press: London, 1972.

59 Sherbourne CD, Stewart AL, Wells KB: Role functioning measures. In: Stewart AL, Ware JE, (eds). Measuring Functioning and WellBeing: The M edical Outcomes Study Approach. Duke University Press: Durham (NC), 1992, pp 205-219.
60 Sherbourne CD: Social functioning: sexual problems measured. In: Stewart AL, Ware JE, (eds). Measuring Functioning and WellBeing: The Medical Outcomes Study A pproach. Duke University Press: Durham (NC), 1992, pp 194-204.

61 Ware JE Jr, Johnston SA, Davies-Avery A, Brook RH: Conceptualisation and measurement of health for adults in the Health Insurance Study, Mental Health 3. Rand report R-1987/3-HEW: Santa Monica (CA), 1979.

62 Snyder DK: Marital Satisfaction Inventory (MSI). Western Psychological Services: Los Angeles (CA), 1981.

63 Horowitz M, Wilner N, Alvarez W: Impact of Event Scale: A measure of subjective stress. Psychosom Med 1979; 41: 209-218.

64 Schreurs PJ, Van de Willige G, Tellegen B, Brosschot JF: de Utrechtse Coping Lijst. Omgaan met problemen en gebeurtenissen. Swets and Zeilinger: Lisse, 1988.

65 Sarason IG, Sarason BR, Shearin EN, Pierce GR: A brief measure of social support: Practical and theoretical implications. J Soc Pers Relationships 1987; 4: 497-510.

66 Olson Dh, Portner J, Lavee Y: FACES III: family adaptability and cohesion evaluation scales. Family Social Science, University of Minnesota: St Paul, 1985.

67 Jong-Grierveld de J, Kamphuis FH: The development of a Raschtype Loneliness Scale. Appl Psych Measurem 1985; 9: 289-299.

68 Almqvist EW, Bloch M, Brinkman R, Craufurd D, Hayden MR: A worldwide assessment of the frequency of suicide, suicide attempts, or psychiatric hospitalization after testing for Huntington Disase. Am J Hum Genet 1999; 64: 1294-1304.

69 Bird TD: Outrageous fortune: the risk of suicide in genetic testing for Huntington Disease. Am J Hum Genet 1999; 64: 1289-1292.

70 Croyle RT, Yi-Chun S, Hart M: Processing risk factor information: Defensive biases in health-related judgments and memory. In: Petrie KJ, Weinman J (eds). Perceptions of Health and IIIness. Harwood Academic Publishers: The Netherlands, 1997.

71 Michie S, Bobrow M, Marteau TM: Predictive genetic testing in children and adults: a study of emotional impact. (submitted).

72 Senior V, Marteau TM, Peters TP: Will genetic testing for predisposition for disease result in fatalism? A qualitative study of parents responses to neonatal screening for familial hypercholesterolaemia. Soc Sci Med 1999; 48: 1857-1860.

73 Nicholas B: Molecular Genetics and Moral Responsibility; 'maybe if I were working on the atom bomb I would have a different argument'. Science Engng Ethics 1999; 5: 515-530. 